\title{
Squamous Cell Carcinoma Masquerading as Rhinophyma
}

\author{
Min Joo Kim, M.D., Hye Sung Kim, M.D., Young Min Park, M.D., Hyung Ok Kim, M.D. \\ Department of Dermatology, Kangnam St. Mary's Hospital, College of Medicine, The Catholic University of Korea, Seoul, Korea
}

\begin{abstract}
A rhinophyma lesion can mask the existence of coexisting occult skin cancers, and many types of tumors can mimic a rhinophyma. Although several coexistent malignant tumors have been reported in patients with rhinophyma, few reports have described the coexistence of rhinophyma and cutaneous squamous cell carcinoma (SCC). Herein, we report on a case of SCC in a 45-year-old man who presented with 2-month-history of a painful, erythematous, globular plaque on the tip of his nose and this lesion mimicked a rhinophyma lesion. The histopathologic examination showed a proliferation of atypical squamous cells that extended into the dermis, which was consistent with SCC. He was treated with surgical excision, and there has been no evidence of recurrence during the follow-up period of 1 year. (Ann Dermatol (Seoul) 21(1) 81 83, 2009)
\end{abstract}

\section{-Keywords-}

Rhinophyma, Squamous cell carcinoma

\section{INTRODUCTION}

Rhinophyma is a kind of phymatous rosacea that occurs most often in men with thick sebaceous $\mathrm{skin}^{1}$. It is characterized by patulous follicular orifices, thickened skin and large nodulocystic lesions clustered over the distal half of the nose $\mathrm{e}^{2}$. Hugely dilated follicles can also be present that contain long vermicular plugs of sebum and keratin. The histologic features are pilosebaceous gland hyperplasia with fibrosis, inflammation and telangiectasia ${ }^{1}$. The clinical diagnosis of rhinophyma is often straightforward, yet there are some cutaneous conditions that may mimic rhin-

Received July 29, 2008, Accepted for publication August 31, 2008

Reprint request to: Hyung Ok Kim, M.D., Department of Dermatology, Kangnam St. Mary's Hospital, College of Medicine, The Catholic University of Korea, 505, Banpo-dong, Seocho-gu, Seoul 137-701, Korea. Tel: 82-2-590-1498, Fax: 82-2-594-3255, E-mail: knderma@ catholic.ac.kr ophyma, including several malignant tumors. The possible clinical differentiating features between rhinophyma and malignant tumors are the drainage, ulceration and rapid growth pattern that are seen only in malignant tumors ${ }^{3}$. In this report, we present a case of infiltrating squamous cell carcinoma (SCC) that occurred on the tip of the nose, and this lesion masqueraded as a rhinophyma.

\section{CASE REPORT}

A 45-year-old man presented with a 2-month history of an enlarging erythematous plaque on the tip of his nose. $\mathrm{He}$ complained of intermittent pain, but he denied pruritus or any other symptoms. He had been treated with a topical retinoid and oral doxycycline for 1 month, with no improvement. His past medical history was unremarkable, and his family history was noncontributory. The physical examination revealed a $3 \mathrm{~cm}$-sized, ill-defined, erythematous, nodular plaque on the nose tip that contained telangiectasias and crusting (Fig. 1).

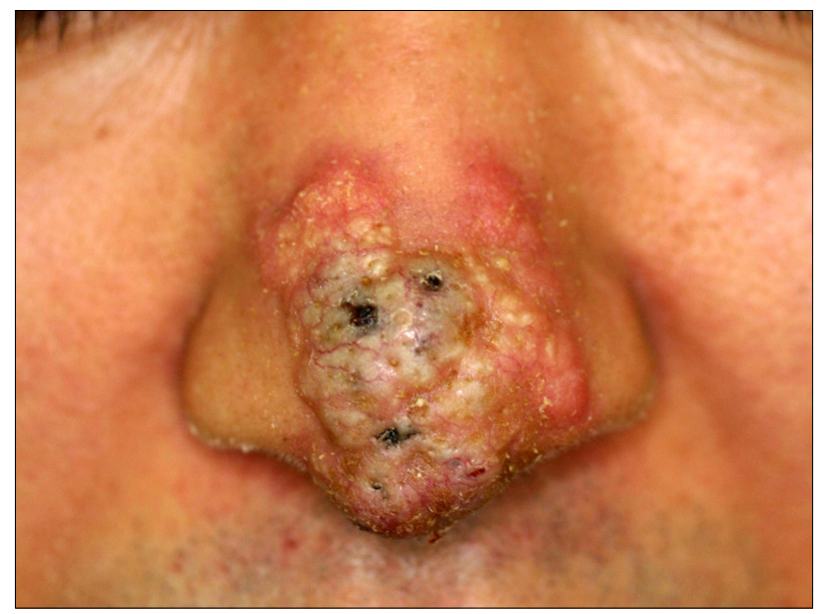

Fig. 1. A solitary, $3 \times 2 \mathrm{~cm}$ sized, irregular shaped, erythematous, nodular plaque with telangiectasia and crusting on the tip of the nose. 

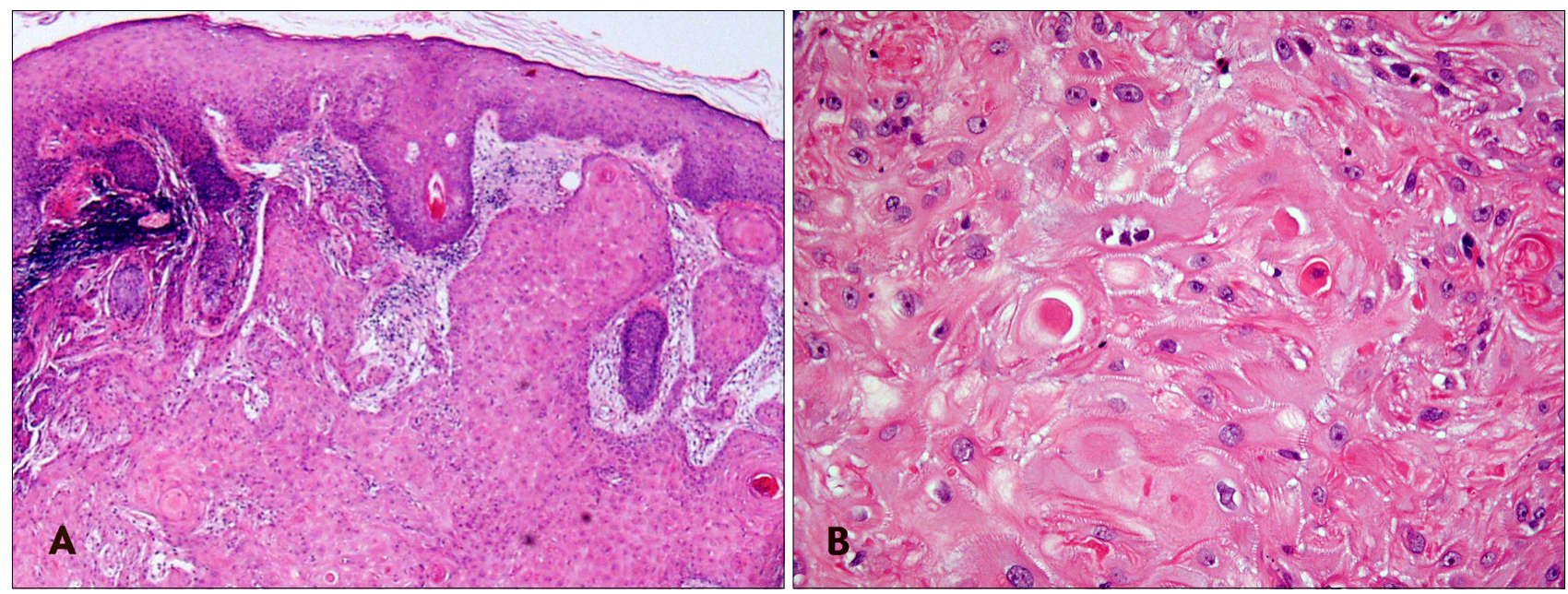

Fig. 2. (A) The histopathologic findings show a tumor invading into the dermis $(H \& E, \times 40)$. (B) The invading tumor is composed of well-differentiated squamous cells that show individual keratinization $(H \& E, \times 400)$.

A skin biopsy specimen was taken from the center of the lesion and this was stained with hematoxylin and eosin. Histologic examination demonstrated an irregular tumor mass throughout the epidermis and dermis (Fig. 2A). The epidermis was characterized by squamous dysplasia, and the invading tumor mass consisted of well-differentiated squamous cells that showed individual keratinization (Fig. 2B). Also present were tumor nests of poorly differentiated atypical squamous cells.

The diagnosis of SCC was made based on these histopathological findings, and further imaging studies, including lung CT and PET-CT, were performed to evaluate for systemic involvement. These imaging studies showed no evidence of distant metastasis or a hidden primary malignancy. The patient was referred to a plastic surgeon, who surgically excised the lesion. No recurrence has been noted during the follow-up period of 1 year.

\section{DISCUSSION}

Wende and Bentz ${ }^{4}$ first reported a connection between malignancy and rhinophyma in 1904. Various malignancies, including basal cell carcinoma ${ }^{5}$, angiosarcoma ${ }^{6}$, $\mathrm{SCC}^{7-9}$ and sebaceous carcinoma ${ }^{10}$, have been reported to coexist with rhinophyma or to resemble it. Furthermore, it has been suggested that the incidence of certain malignancies is markedly increased in patients with rhinophyma when compared to those patients without rhinophyma ${ }^{11}$. However, there is currently insufficient evidence to suggest a secondary transformation of long-standing rhinophyma into any malignancy; it is not known whether rhinophyma predisposes a patient to any malignancy whatsoever.
The diagnosis of rhinophyma is principally based on the clinical features and it is often straightforward. However, several clinical characteristics including drainage, ulceration and a rapid growth pattern may be indicative of a malignancy ${ }^{3}$. In the previous case reports of SCC clinically associated with rhinophyma, all the patients commonly had a long-standing stationary rhinophyma (3 to 20 years) and then it showed unexpected rapid growth and ulcerative change during the several weeks preceding the diagnosis of $\mathrm{SCC}^{7-9}$. In contrast, our case is unique in that he has no previous history of rhinophyma or rosacea, and a rhinophyma-like plaque rapidly developed on the nose tip over such a short period of 2 months. The histopathologic examination revealed well-differentiated squamous cell carcinoma with no evidence of rhinophyma. Thus, as is shown by our case, the unusual growth pattern of a newly formed rhinophyma-like lesion as well as the abrupt clinical changes of a preexisting steady rhinophyma could support the possibility of hidden malignancy rather than a rhinophyma itself.

Once the pathologic diagnosis of SCC is made, a thorough examination should be performed to evaluate whether it is a primary malignancy or a metastatic lesion. In our case, subsequent imaging studies, including lung $\mathrm{CT}$ and PET-CT, showed no evidence of hidden primary internal malignancy, and the patient was finally diagnosed with cutaneous SCC that occurred primarily on the tip of his nose.

Primary cutaneous SCC of the nose is not uncommon, and its reported incidence has ranged from $5.8 \%$ to $7.5 \%$ of all cutaneous SCCs in Korea ${ }^{12-14}$. It is well known that chronic exposure to ultraviolet radiation is the main etiologic factor for the genesis of $\mathrm{SCC}^{15}$. Besides some 
acquired and genetic precancerous skin conditions, some chemical carcinogens have been reported to be involved in the development of SCCs of the nose; the incidence of SCC of the nose is remarkably higher among industrial workers coming in contact with nickel subsulphide, calcium chromate, isopropyl oil and so on ${ }^{16}$. However, this is not such a case because there was no known provoking factor for our patient.

Treatment of a squamous cell carcinoma resembling a rhinophyma is directed by the histologic diagnosis ${ }^{7}$. Nonexcisional ablative techniques, Mohs surgery, conventional surgical excision and radiation therapy are generally considered for treatment ${ }^{17}$.

With respect to the anatomic site, SCCs of the nose tip are not a high risk lesion compared with SCCs of the ear or the lip ${ }^{17}$. Accordingly, rhinophyma-like clinical features do not seem to have a prognostic implication for SCCs. However, the prognosis may be poor as an unfortunate consequence of delayed treatment that's caused by the misdiagnosis of a rhinophyma when considering that rhinophyma is mostly diagnosed clinically without performing a skin biopsy.

Taken together, our case suggests that for managing the patients with a rhinophyma lesion, physicians must be aware of the possibility that the lesion is a true malignancy. Lesions on the nose should be carefully reevaluated when they show no response to conventional therapies, or when any clinical change occurs in them.

\section{REFERENCES}

1. James WD, Berger TG, Elston DM. Andrews' diseases of the skin: clinical dermatology. 10th ed. Philadelphia: Saunders Elsevier, 2006:245-248.

2. Pelle MT. Rosacea. In: Wolff K, Goldsmith LA, Katz SI, Gilchrest BA, Paller AS, Leffell DJ, editors. Fitzpatrick's dermatology in general medicine. 7th ed. New York: McGraw-Hill, 2008:703-708.

3. Lutz ME, Otley CC. Rhinophyma and coexisting occult skin cancers. Dermatol Surg 2001;27:201-202.

4. Wende GW, Bentz CA. Rhinophyma: a pathological analysis of five separate tumors occurring in the same patient. J Cutan Dis 1904;22:447-460.

5. McKenna DJ, McKenna K. Basal cell carcinoma lurking within gross rhinophyma. Clin Exp Dermatol 2006;31:173-174.

6. Aguila LI, Sanchez JL. Angiosarcoma of the face resembling rhinophyma. J Am Acad Dermatol 2003;49:530-531.

7. Broadbent NR, Cort DF. Squamous carcinoma in longstanding rhinophyma. Br J Plast Surg 1977;30:308-309.

8. Kornblut AD, Evers K. Rhinophyma and intranasal carcinoma. J Laryngol Otol 1973;87:1137-1141.

9. Ross DA, Davies MP. Squamous cell carcinoma arising in rhinophyma. J R Soc Med 1992;85:236-237.

10. Motley RJ, Douglas-Jones AF, Holt PJ. Sebaceous carcinoma: an unusual cause of a rapidly enlarging rhinophyma. $\mathrm{Br}$ J Dermatol 1991;124:283-284.

11. Acker DW, Helwig EB. Rhinophyma with carcinoma. Arch Dermatol 1967;95:250-254.

12. Lee JB, Lee SC, Won YH, Chun IK. Clinical and histopathological observation of cutaneous squamous cell carcinoma over 10 years from 1985 to 1994. Korean J Dermatol 1996; 34:775-783.

13. Jang KA, Lee WS, Choi JH, Sung KJ, Moon KC, Koh JK. A clinico-pathological study of squamous cell carcinoma. Korean J Dermatol 2001;39:7-15.

14. Kim YD, Suhr KB, Lee JH, Park JK. A clinical and histopathological study of cutaneous squamous cell carcinoma. Korean J Dermatol 2002;40:25-30.

15. Conley J. Cancer of the skin of the nose. Ann Otol Rhinol Laryngol 1974;83:2-8.

16. Roush GC. Epidemiology of cancer of the nose and paranasal sinuses: current concepts. Head Neck Surg 1979;2:3-11.

17. Grossman D, Leffell DJ. Squamous cell carcinoma. In: Wolff K, Goldsmith LA, Katz SI, Gilchrest BA, Paller AS, Leffell DJ, editors. Fitzpatrick's dermatology in general medicine. 7th ed. New York: McGraw-Hill, 2008:1028-1035. 